\section{Container Medium and Slow-release Nitrogen Fertilizer Influence Growth and Quality of Salvia farinacea}

\author{
Tim C. Knowles ${ }^{1}$, Billy W. Hipp ${ }^{2}$, and Mary Ann Hegemann ${ }^{3}$ \\ Texas Agricultural Experiment Station, Texas A\&M University Research and \\ Extension Center, 17360 Coit Road, Dallas, TX 752.52
}

Additional index words. fertigation, mealy blue sage, native landscape plants, plant analysis, resin-coated fertilizer

\begin{abstract}
We examined responses of Salvia farinacea Benth. (mealy blue sage, a water- and nutrient-efficient native landscape plant for the southern United States) to slow-release (8to 9- month), resin-coated urea $(39 \mathrm{~N}-0 \mathrm{P} 4 \mathrm{~K})$ preplant-incorporated at $0.5,1,2$, or $3 \mathrm{~kg} \mathrm{~N} /$ $\mathrm{m}^{3}$ in 2 perlite: 1 vermiculite (PV) or 2 pine bark: 1 fine sand (BS) (both by volume). This slow-release fertilization was compared to weekly fertigation at $100 \mathrm{mg} \mathrm{N} / \mathrm{liter}$ from ammonium nitrate $(34 \mathrm{~N}-0 \mathrm{P} 4 \mathrm{~K})$. After 21 weeks of greenhouse culture in 3.8-liter containers, shoot dry weight was higher in BS than PV when these media received fertigation or contained slow-release fertilizer at $21 \mathrm{~kg} \mathrm{~N} / \mathrm{m}^{3}$. Shoot dry weight and shoot quality were not increased by exceeding $1 \mathrm{~kg} \mathrm{~N} / \mathrm{m}^{3}$ in PV or $2 \mathrm{~kg} \mathrm{~N} / \mathrm{m}^{3}$ in BS. Fertigation resulted in shoot dry weight and shoot quality equal to the highest values achieved with slow-release fertilizer. Cate-Nelson analysis showed that shoot $\mathbf{N}$ concentration should be $\geq 4.0 \%$ for this element not to limit plant growth.
\end{abstract}

Mealy blue sage is a drought-tolerant, nutrient-efficient native herbaceous perennial well adapted to southern landscapes in U.S. Dept. of Agriculture hardiness zones 7 through 10. It has shrubby stems that can be $0.6 \mathrm{~m}$ tall and glossy-green lanceolate leaves up to $0.2 \mathrm{~m}$ long. Violet-blue and white tubular flowers, each $1.25 \mathrm{~cm}$ long with a white spot, are borne in racemes up to $0.2 \mathrm{~m}$ long. Mealy blue sage has a mounding growth habit reaching $0.6 \mathrm{~m}$ in diameter and blooms from March until November in southern climates. It is easily propagated from seed or cuttings and, from seed, quickly reaches a marketable 3.8-liter container size in 20 weeks.

Recently, increased demand for resourceefficient native landscape plants by nurseries and homeowners has prompted research in propagating and producing these plants (Hipp et al., 1988, 1989).

Nutrients are applied to container-grown plants by injecting soluble fertilizers into irrigation systems (fertigation) or as slow-release, dry formulations topdressed or preplant-in-

Received for publication 7 May 1992. Accepted for publication $10 \mathrm{Feb} .1993$. Technical article no. 30528 of the Texas Agricultural Experiment Station, Texas A\&M Univ., College Station. We thank Tom Reid of Sierra Chemical Co., Milpitas, Calif., for providing the slow-release $\mathrm{N}, \mathrm{P}$, and $\mathrm{K}$ formulations. Mention of trade names or commercial products does not constitute endorsement or recommendation for use by the Texas Agricultural Experiment Station. The cost of publishing this paper was defrayed in part by the payment of page charges. Under postal regulations, this paper therefore must be hereby marked advertisement solely to indicate this fact.

Research Associate.

${ }^{2}$ Professor.

Research Technician. corporate in the medium. Fertigation systems can be manipulated to supply nutrients commensurate with plant needs, but considerable waste due to leaching from within and runoff between containers can occur. Dry slow-release fertilizers often are resin-coated soluble nutrients whose release is controlled primarily by temperature and resin coating type. Consequently, this controlled nutrient release over time (from incorporated slowrelease fertilizer) can reduce $\mathrm{N}$ fertilizer losses, thus potentially reducing nitrate contamination of ground and surface water. Resin-coated, slow-release fertilizers have been studied for use on woody ornamental (Gouin and Link, 1973; Ward and Whitcomb, 1979) and foliage (Gilliam et al., 1983) plants. Optimum application rate varied between species, normally ranging from 0.5 to $2 \mathrm{~kg} \mathrm{~N} / \mathrm{m}^{3}$ of growth medium. To date, slow-release fertilizer requirements of resource-efficient native landscape plants have not been examined.

Nutrient requirements of container-grown ornamental plants also are influenced by medium composition (Brown and Emino, 1981; Sartain and Ingram, 1984). Soilless media have a wide range of cation-exchange capacities depending on ratios and types of components in the mix. In most media, adsorbed cations in equilibrium with the medium solution may act as a temporary buffer to reduce nutrient concentrations in the medium solution after leaching or plant nutrient uptake (Wright and Nemiera, 1987). Organic media components, such as pine bark, leach soluble $\mathrm{N}$ rapidly and sorb ammonium ions (Thomas and Perry, 1980). Nevertheless, the effect of medium composition for optimum preplant application rates of slow-release fertilizers has not been documented for resource-efficient plants. Research was conducted at the Texas
Agricultural Experiment Station, Dallas, to determine early responses to slow-release $\mathrm{N}$ fertilizer and critical tissue $\mathrm{N}$ concentration of finished 3.8-liter container-grown mealy blue sage plants in two media.

Ten-week-old, 10-cm-tall Salvia farinacea seedlings were placed in 3.8-liter plastic pots containing 2 perlite : 1 vermiculite (PV) or 2 hammer-milled pine bark :1 fine sand (BS) (both by volume). These two media had bulk densities of 0.145 and $0.580 \mathrm{~g} / \mathrm{cc}$, and of $22 \%$ and $30 \%$ moisture by volume at container capacity, respectively. Although PV is not a common nursery mix, it seemed to be one of the best combinations for growing southern native plants (B.W. Hipp and B.J. Simpson, unpublished data). Slow-release N was preplant-incorporated into each medium as 8- to 9-month-release resin-coated urea (Osmocote 39N-0P-0K; Sierra Chemical Co., Milpitas, Calif.). Dolomitic limestone, calcium phosphate $(17 \% \mathrm{P})$, potassium sulfate $(37 \% \mathrm{~K})$, and micronutrients (Micromax; Sierra Chemical Co.) also were preplant-incorporated into each medium at $3,2.5,2$, and $1 \mathrm{~kg} \cdot \mathrm{m}^{-3}$, respectively. Slow-release $\mathrm{N}$ application rates were $0.5,1,2$, and $3 \mathrm{~kg} \mathrm{~N} / \mathrm{m}^{3}$. One additional $\mathrm{N}$ treatment consisted of a weekly application of $100 \mathrm{mg} \mathrm{N} / \mathrm{liter}$ as ammonium nitrate $(34 \mathrm{~N}$ $0 \mathrm{P}-0 \mathrm{~K})$ solution, allowing $\approx 300 \mathrm{ml}$ drainage per pot. This $\mathrm{N}$ fertigation treatment resulted in near-optimum growth of southern native plants (Hipp et al., 1988, 1989) and allowed us to compare fertigation and slow-release fertilization. Plants were irrigated with $800 \mathrm{ml}$ tap water per container on day $\mathrm{O}$ and $500 \mathrm{ml}$ per container thereafter as required. Irrigation water contained negligible $\mathrm{N}$ and had an electrical conductivity of $0.3 \mathrm{dS} \cdot \mathrm{m}^{-1}$. Treatments were replicated four times in a completely randomized $5(\mathrm{~N}) \times 2$ (media) factorial arrangement. The study was conducted in a greenhouse receiving natural light at 21 to $27 \mathrm{C}$ from 20 Feb. to 25 Apr. 1990

Plants were cut at medium level 21 weeks after transplanting, dried at $65 \mathrm{C}$, weighed, and analyzed for tissue $\mathrm{N}$ concentration. Plant tissue total $\mathrm{N}$ concentration was determined by digestion (Gallaher et al., 1976) and automated steam distillation and titration. Visual quality ratings also were determined at harvest. At the end of the study, $\mathrm{PV}$ pH was 6.5 and that of BS was 6.2.

Salvia farinacea shoot dry weight was affected significantly by the fertilizer $\times$ medium interaction (Table 1). Shoot dry weight with slow-release fertilizer rates exceeding $0.5 \mathrm{~kg}$ $\mathrm{N} / \mathrm{m}^{3}$ or from liquid fertilizer was higher in BS than in PV. Irrespective of growth medium, weekly fertigation with $100 \mathrm{mg}$ N/liter resulted in shoot dry weight equal to the highest achieved with slow-release N. Although shoot dry weight responded quadratically to increasing slow-release fertilizer rate $\left(r^{2}=0.72\right.$ for PV and 0.83 for BS), these weights were not increased significantly by exceeding $1.0 \mathrm{~kg} \mathrm{~N} /$ $\mathrm{m}^{3}$ in $\mathrm{PV}$ or $2 \mathrm{~kg} \mathrm{~N} / \mathrm{m}^{3}$ in BS. The greater water-holding (container) capacity of BS may have contributed to the higher shoot dry weight with BS than with PV; however, the available water contents of these media are unknown. 
Table 1. Effect of growth medium and $\mathrm{N}$ fertilizer on dry weight, quality, and $\mathrm{N}$ uptake of Salvia farinacea shoots 21 weeks after seeding.

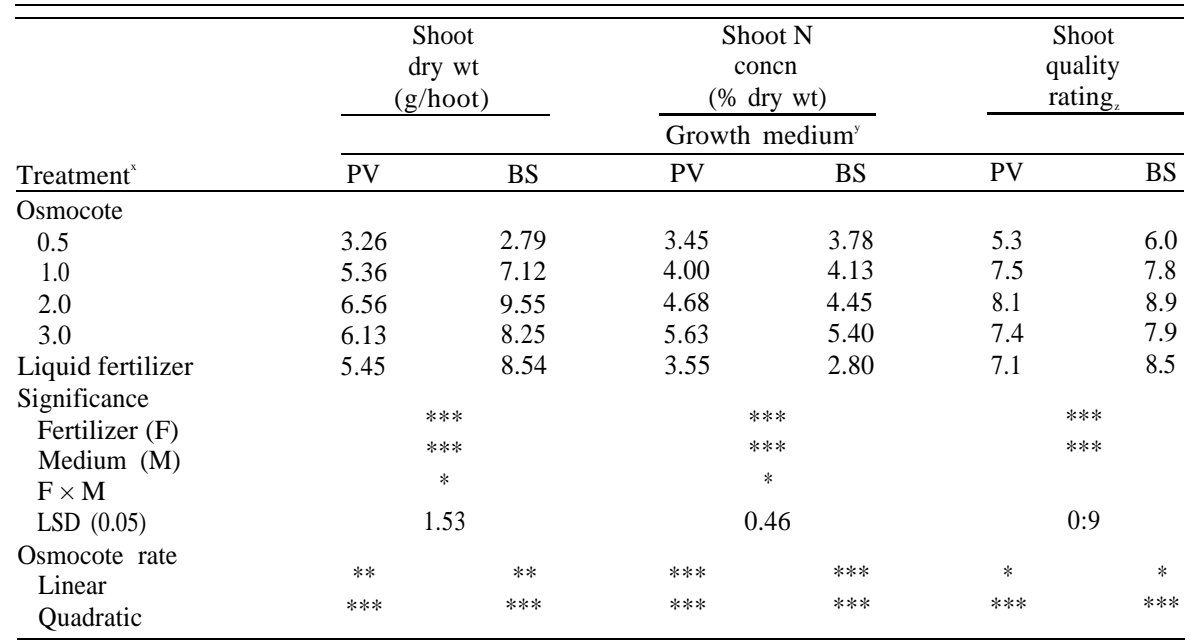

${ }^{2}$ Visual quality ratings were based on foliage color, growth compactness, and overall marketability on a scale of 0 (dead) to 9 (excellent); those with ratings $<5$ were considered unmarketable.

${ }^{y} \mathrm{PV}=2$ perlite $: 1$ vermiculite, $\mathrm{BS}=2$ pine bark $: 1$ sand.

${ }^{x}$ Osmocote $=$ slow-release fertilizer $(39 \mathrm{~N}-0 \mathrm{P}+0 \mathrm{~K})$ applied at four rates $\left(\mathrm{kg} \mathrm{N} / \mathrm{m}^{3}\right)$; liquid fertilizer $=34 \mathrm{~N}$ OP-0K applied weekly ( $100 \mathrm{mg} \mathrm{N} / \mathrm{liter}$ ).

Ns, $, * *, * *$ Nonsignificant or significant at $P \leq 0.05,0.01$, or 0.001 , respectively.

Sorption of ammonium by pine bark (Foster et al., 1983) may have reduced $\mathrm{N}$ leaching losses from $\mathrm{BS}$ relative to $\mathrm{PV}$, thereby resulting in higher shoot dry weight of plants growing in BS than in PV when slow-release fertilizer rates exceeded $0.5 \mathrm{~kg} \mathrm{~N} / \mathrm{m}^{3}$. With slow-release fertilizer applied at $3 \mathrm{~kg} \mathrm{~N} / \mathrm{m}^{3}$ in both media, plants were leggy and lodged, a result indicating excessive plant succulence.

Shoot $\mathrm{N}$ concentration also was affected significantly by the fertilizer $\mathrm{x}$ medium interaction (Table 1). At each level of slow-release fertilizer, shoot $\mathrm{N}$ concentrations were the same for plants growing in PV and BS. With $100 \mathrm{mg} \mathrm{N} /$ liter of liquid fertilizer, however, plants growing in PV had higher shoot $\mathrm{N}$ concentrations than those growing in BS. Consequently, fertigation resulted in a shoot $\mathrm{N}$ concentration equal to that achieved with 0.5 $\mathrm{kgN} / \mathrm{m}^{3}$ from slow-release fertilizer in $\mathrm{PV}$, but in a lower shoot $\mathrm{N}$ concentration than was achieved with $0.5 \mathrm{~kg} \mathrm{~N} / \mathrm{m}^{3}$ from slow-release fertilizer in BS. Shoot N concentration responded quadratically to increasing slow-release fertilizer rate $\left(r^{2}=0.85\right.$ for $\mathrm{PV}$ and 0.83 for BS), with $\mathrm{N}$ concentration values increasing significantly through the range of slow-release $\mathrm{N}$ fertilizer rates.

Irrespective of fertilizer treatment, shoot quality was higher for plants growing in BS than in PV (Table 1). Shoot quality responded quadratically to increasing slow-release fertilizer rate; however, shoot quality was not increased significantly by exceeding $1 \mathrm{~kg} \mathrm{~N} / \mathrm{m}^{3}$ of slow-release fertilizer in PV or $2 \mathrm{~kg} \mathrm{~N} / \mathrm{m}^{3}$ in BS. Fertigation with $100 \mathrm{mg}$ N/liter resulted in shoot quality equal to that achieved with 1.0 $\mathrm{kg} \mathrm{N} / \mathrm{m}^{3}$ from slow-release fertilizer in both media.

Cate and Nelson developed a graphical method for partitioning the yield vs. soil-test nutrient level into two groups (Nelson and Anderson, 1977). Using this method, it is possible to determine a critical shoot $\mathrm{N}$ con- centration that separated plants into two groups: those for which probability of growth response to $\mathrm{N}$ was very large or those for which such probability was very small. Shoot $\mathrm{N}$ concentrations were ranked by shoot dry weight to determine tissue test classes. Cate-Nelson analysis resulted in a critical level of $4.0 \% \mathrm{~N}$ in 21-week-old $S$. farinacea seedlings growing in either PV or BS $\left(r^{2}=0.503\right)$. While shoot $\mathrm{N}$ concentrations exceeding the $4 \%$ critical level were achieved with slow-release fertilizer at 1 to $3 \mathrm{~kg} \mathrm{~N} / \mathrm{m}^{3}$ of PV or BS, fertigating BS resulted in only $2.8 \% \mathrm{~N}$ in shoots that were of the same dry weight and quality achieved with slow-release fertilizer at 1 to $3 \mathrm{~kg} \mathrm{~N} / \mathrm{m}^{3}$. These results suggest that the Cate-Nelson analysis overestimated shoot critical $\mathrm{N}$ concentration and that plants supplied with slow-release fertilizer were subjected to luxury $\mathrm{N}$ consumption. The $4 \%$ critical shoot $\mathrm{N}$ level is higher than that reported by Hipp et al. $(1988,1989)$ for two species of native Texas plants receiving soluble $\mathrm{N}$ applications in irrigation water. This difference also could be due to genetic differences among species and to the more rapid growth of $S$. farinacea than of other native Texas landscape plants.

Resin-coated, slow-release fertilizers, when preplant-incorporated into media, continuously release nutrients, providing the soil is moist and soil temperature is suitable for resin permeability. Since both media were provided the same standard irrigation, differences in growth response due to physical properties of the media, such as water-air relationships, represent media effects. Although BS has a greater water-holding capacity than PV, the available water content of each is unknown. Nutrients released in the first 5 to 8 weeks from slow-release fertilizers are of great importance for nursery crop culture. Ashwin and Sharma ( 1977) found that N recovery in plant tissue as a percentage of $\mathrm{N}$ applied varied with the release rate of resin-coated Osmocote and time of analysis. Therefore, the optimum $\mathrm{N}$ application rates and critical shoot $\mathrm{N}$ levels determined in our study for 8- to 9-month resin-coated Osmocote may differ from slow-release fertilizers with different $\mathrm{N}$ release rates.

Foster et al. (1983) and Thomas and Perry (1980) showed that substantial amounts of ammonium-N from fertilizers are absorbed to pine bark in a growing medium. Additionally, microbial decomposition of cellulose material in pine bark can initially immobilize $\mathrm{N}$ fertilizer incorporated in a pine bark medium and result in higher $\mathrm{N}$ requirements at planting (Allison et al., 1963). Thus, there is general consensus that incorporating ammonium $\left(\mathrm{NH}_{4}\right)$ into a pine bark medium may be advisable to prevent low $\mathrm{N}$ levels from occurring in the container solution due to $\mathrm{NH}_{4}$ binding when plants are first potted and fertilized. Once equilibrium is reached, $\mathrm{N}$ in solution is readily leached from pine bark therefore, careful attention must be given to $\mathrm{N}$ levels in the container medium solution after irrigation or rainfall. Although we did not measure $\mathrm{NH}_{4}$ sorption in this study, it might explain the higher slow-release $\mathrm{N}$ application rate required for maximum shoot dry weight of plants grown in BS than PV. Further work should examine initial $\mathrm{NH}_{4}$ sorbed by, and leaching losses of, $\mathrm{N}$ from media containing different slow-release fertilizer rates.

Our results indicated that BS resulted in greater shoot growth of 21-week-old $S$. farinacea plants than PV. Shoot growth and quality of plants growing in bark-sand were maximal with either weekly $100 \mathrm{mg}$ N/liter (as ammonium nitrate, $34 \mathrm{~N}-0 \mathrm{P}-0 \mathrm{~K}$ ) fertigation or preplant incorporation of slow-release $\mathrm{N}$ fertilizer (Osmocote $39 \mathrm{~N}-0 \mathrm{P}-0 \mathrm{~K}, 8$ - to 9 -month release) at $2 \mathrm{~kg} \mathrm{~N} / \mathrm{m}^{3}$. These research findings furnish slow-release $\mathrm{N}$ fertilizer guidelines for container production of $S$. farinacea, a resource-efficient native landscape plant

\section{Literature Cited}

Allison, F.E., R.M. Murphy, and C.J. Klein. 1963. Nitrogen requirements for the decomposition of various kinds of finely ground woods in soil. Soil Sci. 96:187-191.

Ashwin, A.J. and G.C. Sharma. 1977. Nitrogen release characteristics of controlled-release fertilizers during a four month soil incubation. J. Amer. Soc. Hort. Sci. 102:364-367.

Brown, O.D.R. and E.R. Emino. 1981. Response of container grown plants to six consumer growing media. HortScience 16:78-80.

Foster, W. J., R.D. Wright, M.M. Alley, and T.H. Yeager. 1983. Ammonium adsorption on a pine-bark growing medium. J. Amer. Soc. Hort. Sci. 108:548-551.

Gallaher, R.N., C.O. Welson, and F.C. Boswell 1976. A semi-automatic procedure for total nitrogen in plant and soil samples. Soil Sci. Soc. Amer. J. 40:887-889.

Gilliam, C.H., R.L. Shumack, and C.E. Evans. 1983. The effects of slow-release fertilizers on the growth and postproduction performance of Boston fem. HortScience 18:442-444.

Gouin, F.R. and C.B. Link. 1973. Growth response of container-grown woody ornamental to slow-release fertilizers. HortScience 8:208-209.

Hipp, B.W., B.J. Simpson, and P.S. Graff. 1988. 
Influence of nitrogen and phosphorus on growth and tissue $\mathrm{N}$ and $\mathrm{P}$ concentration in Salvia greggii. J. Environ. Hort. 6:59-61.

Hipp, B. W., B.J. Simpson, and P.S. Chaff. 1989. Influence of phosphorus on nitrogen fertilizer requirement of Melampodium leucanthum (blackfoot daisy) grown in perlite-vermiculite medium. J. Environ. Hort. 7:83-85.

Nelson, L.A. and R.L. Anderson. 1977. Partitioning of soil test-crop response probability, p. 19-38. In: T.R. Peck, J.T. Cope, Jr., and D.A. Whitney (eds.). Soil testing: Correlating and interpreting the analytical results. Amer. Soc. Agron. \& Soil Sci. Soc. Amer., Madison, Wis. Spec. Publ. 29. Sartain, J.B. and D.L. Ingram. 1984. Influence of container medium, lime, and nitrogen source on growth of woody ornamentals. J. Amer. Soc. Hort. Sci. 109:882-886.
Thomas, S. and F.B. Perry, Jr. 1980. Ammonium nitrogen accumulation and leaching from an all pine bark medium. HortScience 15:824-825.

Ward, J.D. and C.E. Whitcomb. 1979. Nutrition of Japanese holly during propagation and production. J. Amer. Soc. Hort. Sci. 104:523-526.

Wright, R.D. and A.X. Niemiera. 1987. Nutrition of container grown woody nursery crops. Hort. Rev. 9:75-101. 